\title{
Public Libraries in Canada: An Overview
}

Virginia Wilson, MA, MLIS

Coordinator, Saskatchewan Health Information Resources Partnership (SHIRP)

University of Saskatchewan

Saskatoon, Saskatchewan, Canada

virginia.wilson@usask.ca

\begin{abstract}
$\underline{\text { ABSTRACT }}$
Purpose - This overview compiles information pertaining to Canadian public libraries in the areas of legislation, structure, governance, and funding models, and briefly describes issues common to public libraries across the country.

Methodology/Approach - Information was gathered by consulting the most recent versions of provincial and territorial legislation that governs public libraries, as well as by referring to various websites at the provincial, territorial, and national level. After a general overview of public libraries in Canada, this paper provides individual examination of each province and territory.
\end{abstract}

Findings - Many commonalities and some differences exist across most provinces and territories in Canada with regard to public libraries in terms of legislation, structure, governance, and funding models.

Originality/value - This paper brings together in one document comparable information about how public libraries are structured, governed, and funded across Canada.

Paper type - General review

Keywords - Public libraries, Legislation, Canadian public libraries, Canadian library legislation

\section{INTRODUCTION}

Various versions of public (and semi-public) lending institutions have existed in Canada over the past 200 years, but the public library system as it looks now emerged during the period of time between the late 1930s and into the 1960s. This was a period of rapid growth, with both regional public library systems and the National Library of Canada emerging as functioning institutions. The development of regional library systems was designed to support the evolution of rural 
Canada. Trained staff, union library catalogues, and library networks were only a few of the services provided by the regional library systems. The National Library of Canada was established by Parliament in 1953 as a result of a report submitted by the Royal Commission on National Development in the Arts, Letters and Sciences, often referred to as the 'Massey Commission' after the group's chair, Vincent Massey, who was at the time chancellor of the University of Toronto. The National Library essentially mirrored on a national level what the regional library systems were doing at the local level: a national system of libraries emerged, and along with it, a national union catalogue and an organization that could foster sharing among all libraries and library sectors across Canada. In a country with a large land mass and a widely distributed population, public libraries continue to provide much-needed services to all communities.

The basis for this paper was a request from the Dean of the University of Saskatchewan Library for the compilation of an overview of public libraries in Canada to inform her current research. The need for this information to be compiled in one place became evident when it was found not to exist anywhere else. This paper also developed from a personal interest in public libraries, as well as evidence based librarianship (EBL). One of the premises of EBL is that if the information or evidence is not available to answer a particular question, then the answer should be found and disseminated in order to help develop the body of evidence in librarianship. Information was gathered by consulting the most recent versions of provincial and territorial legislation that governs public libraries in Canada, as well as by referring to various library websites at the provincial, territorial, and national level. This paper outlines the current structure of public libraries in Canada in a general sense as well as by province and territory. Select issues of importance to Canadian public libraries are briefly outlined.

\section{PUBLIC LIBRARIES: AN OVERVIEW}

An overview of public libraries in Canada necessarily must begin with a brief description of the governmental structure of the country. Canada operates under the principle of federalism that has evolved into a highly decentralized one. There are two constitutionally autonomous levels of government: the federal government and the provincial governments. The federal government is responsible for certain set of functions, such as defence, foreign affairs, currency, and transfer 
payments to the provinces. The provinces are responsible for major social and public services, such as healthcare, education, welfare, and the public library system (which often falls under the auspices of departments of education) (Boadway, 2006). The advantage of the decentralized federation is that provinces can tailor social programs to meet the distinct and diverse needs of their constituents. It should be noted that territorial governments are unlike the provincial governments, as they are not constitutionally recognized entities, and instead, fall under the jurisdiction of the federal government. However, in practice, they are accorded many of the privileges that the provinces have (Mapleleafweb, 2008). Thus the overarching structure is constructed in a way that provincial governments have a certain level of autonomy, and public libraries fall under the provincial side of the model.

Public libraries in Canada's 10 provinces and three territories are under the auspices of their respective provincial and territorial governments. Almost all public libraries are governed by a library act—provincial or territorial legislation designed to outline governance and functional duties and purposes of public libraries. The exception to this is Quebec, as will be outlined below. In general, funding largely comes from the province or territory, often with additional, supporting funding received from participating municipalities and, to a lesser extent, from federal programs and initiatives. The funding model by and large looks like this: the provincial or territorial government provides funding for public libraries on a per capita basis, as long as the municipality also contributes a certain amount on a per capita basis. Often the municipality will levy a special library tax for this purpose. The municipality is usually responsible for funding the physical facility. There are variations to this model. In some instances, municipal funding can be negligible, while federal funding can be substantial. Often, funding in small chunks comes from other organizations, including non-profit organizations, for-profit corporations in the form of sponsorships, fundraising by individual libraries, and one-time gifts. Funding is often complex, as it usually involves operating grants, grants for network infrastructure, grants for digital content, and more. As per a decentralized federation, funding is tailored to each specific province, its needs, and what it can support. Some provinces have a very large per capita chunk of funding coming from local versus provincial sources. However, others have a larger percentage of funding coming from the province. In Newfoundland/Labrador, for example, it is suspected that if funding was not primarily from the province, many of the library sites would 
close. More details of particular funding arrangements will be explored when looking at the individual provinces and territories.

Most public libraries in Canada are overseen at the local level by library boards. Board members include members of local governments, volunteers, and others. Library boards oversee and set budgets and policy, and are responsible for bigger picture planning, while day to day operations are carried out by library staff. In many cases, the library boards are corporations. In terms of fees for library services, the no fee approach is almost universal across Canada. A fee may be charged to people who live outside of the province or territory where they are attempting to get a library card, but residents usually are not. Notable exceptions include Alberta and Quebec, as will be outlined below.

Although the terminology is different across Canada, most provinces and territories employ a similar structure pertaining to public libraries. Public libraries are the responsibility of a particular ministry or department of the provincial/territorial government. There is often an overarching body or group under the auspices of that ministry or department: a Provincial Library or Provincial/Territorial Library Services that is run by a professional librarian (Provincial Librarian or Public Library Director). The provincial and territorial agencies responsible for public libraries can vary, but their functions are generally the same: to provide advice on policy, coordinate funding and services, administer grants, and develop and monitor legislation pertaining to public libraries. Under this body are the regional library systems, comprised of local public libraries within a prescribed area of land, and overseen by a head office that coordinates and provides library services such as interlibrary loans, collections, cataloguing, etc. There are also joint venture libraries, where two entities in a small community will band together to provide library services. These often fall under the jurisdiction of the regional library system. The most common example of a joint venture library is a school/public library. Larger urban centers will often have their own public library system outside of a regional library system. For example, the cities of Saskatoon and Regina in the province of Saskatchewan are municipal public library systems in their own right, and do not belong to a regional library system. Several of the provincial and territorial Library Acts have clauses mandating or approving partnerships with various groups including Aboriginal bands. 
Further to the differences in nomenclature, the table below outlines the different library types found across Canada. The names do vary but the functions are often the same across similar terms. The term "municipal libraries" is common, and it can be equated with "county libraries," and "local libraries.” Regional library districts or systems are much like "library systems” and “district libraries.” Definitions describing the various nuances of the different terms were not found when this information was compiled from the sources indicated. Because each province and territory is responsible for its own public library system, the differences in terminology and the lack of definitions to be found is understandable.

Table I: Legislation and Library Types*

\begin{tabular}{|l|l|l|}
\hline Province & Legislation & Library Types \\
\hline British Columbia & British Columbia Library Act & $\begin{array}{l}\text { Municipal Libraries } \\
\text { Regional Library District } \\
\text { Public Library Associations } \\
\text { Integrated Public Library Systems } \\
\text { Federated Public Library Systems }\end{array}$ \\
\hline Alberta & Alberta Public Libraries Act & $\begin{array}{l}\text { Municipal Libraries } \\
\text { Library systems } \\
\text { Community Libraries } \\
\text { Federations }\end{array}$ \\
\hline Saskatchewan & $\begin{array}{l}\text { Public Libraries Act; Libraries } \\
\text { Co-operation Act }\end{array}$ & $\begin{array}{l}\text { Municipal or Local Libraries } \\
\text { Regional Library Systems } \\
\text { The Northern Library System }\end{array}$ \\
\hline Manitoba & $\begin{array}{l}\text { Public Libraries Act; City of } \\
\text { Regional Libraries }\end{array}$ \\
& Winnipeg Act (Winnipeg PL) & Federations (regional/municipal) \\
\hline Ontario & Ontario Public Libraries Act & $\begin{array}{l}\text { Public Libraries } \\
\text { Union Libraries } \\
\text { County Libraries }\end{array}$ \\
\hline Quebec & & Municipally integrated \\
\hline New Brunswick & No legislation & $\begin{array}{l}\text { Partnerships (provincial } \\
\text { government and municipalities) }\end{array}$ \\
\hline Prince Edward Island & Public Libraries Act & $\begin{array}{l}\text { Community Libraries } \\
\text { District Libraries }\end{array}$ \\
\hline Nova Scotia & Libraries Act & $\begin{array}{l}\text { Municipal Libraries } \\
\text { Regional Library Systems }\end{array}$ \\
\hline & Public Libraries Act & $\begin{array}{l}\text { Local Libraries } \\
\text { Regional Libraries }\end{array}$ \\
\hline & & \\
\hline
\end{tabular}

\footnotetext{
* The author acknowledges and thanks Dr. Vicki Williamson, Dean, University of Saskatchewan Library for the prototype upon which this and the following table are based.
} 


\begin{tabular}{|l|l|l|}
\hline & \multicolumn{1}{|c|}{} & St. John's Public Library \\
\hline Yukon Territory & $\begin{array}{l}\text { Yukon Territory Public Libraries } \\
\text { Act }\end{array}$ & $\begin{array}{l}\text { Central Library } \\
\text { Community Libraries } \\
\text { Whitehorse Public Library }\end{array}$ \\
\hline Northwest Territories & $\begin{array}{l}\text { Northwest Territories Library } \\
\text { Act }\end{array}$ & $\begin{array}{l}\text { Community Libraries } \\
\text { Virtual Libraries } \\
\text { Yellowknife Public Library }\end{array}$ \\
\hline Nunavut & $\begin{array}{l}\text { Northwest Territories Library } \\
\text { Act }\end{array}$ & Community Libraries \\
\hline
\end{tabular}

Table II: Governance and Funding

\begin{tabular}{|c|c|c|}
\hline Province & $\begin{array}{l}\text { Public Library Governance } \\
\text { (provincial level and local level) }\end{array}$ & Funding \\
\hline British Columbia (BC) & $\begin{array}{l}\text { - Public Library Services } \\
\text { Branch of the BC Ministry of } \\
\text { Education } \\
\text { - Library Boards }\end{array}$ & $\begin{array}{l}\text { Per Capital Operating Grants from } \\
\text { the province (dependent on } \\
\text { municipal contribution) }\end{array}$ \\
\hline Alberta & $\begin{array}{l}\text { - Libraries, Community, and } \\
\text { Voluntary Services Sector of } \\
\text { Alberta Community } \\
\text { Development } \\
\text { - Library Boards }\end{array}$ & $\begin{array}{l}\text { Community Development Grants } \\
\text { dependent on the Board's securing } \\
\text { of a certain level of municipal } \\
\text { funding. Smaller community } \\
\text { boards receive flat grants. Each } \\
\text { system board receives provincial } \\
\text { operating grants. }\end{array}$ \\
\hline Saskatchewan & $\begin{array}{l}\text { - Saskatchewan Department of } \\
\text { Learning (The Provincial } \\
\text { Library) } \\
\text { - Library Boards } \\
\end{array}$ & $\begin{array}{l}\text { Three provincial funding pools: } \\
\text { regional libraries, municipal } \\
\text { libraries, and the Northern Library } \\
\text { system. }\end{array}$ \\
\hline Manitoba & $\begin{array}{l}\text { Public Libraries Services } \\
\text { Branch, Department of } \\
\text { Culture, Heritage and Tourism } \\
\text { - Governing Library Boards } \\
\text { (except Winnipeg Public } \\
\text { Library, which has an } \\
\text { Advisory Board) }\end{array}$ & $\begin{array}{l}\text { Matching provincial per capita } \\
\text { grants. }\end{array}$ \\
\hline Ontario & $\begin{array}{l}\text { - Programs and Services } \\
\text { Branch, Ministry of Culture } \\
\text { and Ontario Library Service } \\
\text { North and the South Ontario } \\
\text { Library Service } \\
\text { - Library Boards }\end{array}$ & $\begin{array}{l}\text { Provincial operating grants; } \\
\text { municipal grants; First Nation } \\
\text { library grants }\end{array}$ \\
\hline Quebec & $\begin{array}{l}\text { - A law under the Ministère de } \\
\text { la Culture } \\
\text { - Libraries are municipally } \\
\text { integrated as basic municipal }\end{array}$ & Municipally directed \\
\hline
\end{tabular}




\begin{tabular}{|c|c|c|}
\hline & $\begin{array}{l}\text { services (no library board } \\
\text { governance) }\end{array}$ & \\
\hline New Brunswick (NB) & $\begin{array}{l}\text { - New Brunswick Public } \\
\text { Library Services, Department } \\
\text { of Post-Secondary Education, } \\
\text { Training, and Labour } \\
\text { - NB Public Libraries Board, } \\
\text { library boards }\end{array}$ & $\begin{array}{l}70 \% \text { provincial funding; } 30 \% \\
\text { municipal funding }\end{array}$ \\
\hline Prince Edward Island & $\begin{array}{l}\text { - Ministry of Cultural Affairs, } \\
\text { Division of Culture, Heritage, } \\
\text { and Libraries } \\
\text { - Library Boards }\end{array}$ & $\mathrm{n} / \mathrm{a}$ \\
\hline Nova Scotia & $\begin{array}{l}\text { - Department of Education } \\
\text { - Library Boards }\end{array}$ & Provincial and municipal \\
\hline $\begin{array}{l}\text { Newfoundland/Labrad } \\
\text { or }\end{array}$ & $\begin{array}{l}\text { - Provincial Information and } \\
\text { Library Resources Board } \\
\text { - Library Boards }\end{array}$ & $\begin{array}{l}\text { Primarily provincial; municipal } \\
\text { contributions are often "in kind" }\end{array}$ \\
\hline Yukon Territory & $\begin{array}{l}\text { Public Libraries Unit, } \\
\text { Community Development } \\
\text { Branch of the Department of } \\
\text { Community Services } \\
\text { - Library Boards }\end{array}$ & Per-capita provincial funding \\
\hline $\begin{array}{l}\text { Northwest Territories } \\
\text { (NWT) }\end{array}$ & $\begin{array}{l}\text { - NWT Public Library Services, } \\
\text { a unit of Education, } \\
\text { Operations and Development, } \\
\text { Department of Education } \\
\text { - Municipal Governments }\end{array}$ & Specific to each community \\
\hline Nunavut & $\begin{array}{l}\text { - Nunavut Public Library } \\
\text { Services, Division of Culture } \\
\text { and Heritage in the Nunavut } \\
\text { Department of Culture, } \\
\text { Language, Elders, \& Youth } \\
\text { - Library boards }\end{array}$ & $\begin{array}{l}\text { Territorial government funding in } \\
\text { combination with community } \\
\text { contribution. Additional } \\
\text { partnerships with public and } \\
\text { private organizations }\end{array}$ \\
\hline
\end{tabular}

\section{PROVINCIAL AND TERRITORIAL OVERVIEWS}

Because the variety of nomenclature used and the different permutations of public libraries across Canada, what follows is an outline of each province's public library structure, governance, and funding models will follow. Tables I and II provide a condensed overview of the provinces and territories. 


\section{British Columbia (BC)}

The British Columbia Library Act makes mention of five types of public libraries: municipal libraries, regional library districts, public library associations, integrated public library systems, and federated public library systems. The latter two, if in operation prior to August 1994, may continue to operate subject to the legislation. It is unclear if any of these two types of public libraries have been formed since August 1994. Each type of public library and library system is governed by a library board comprised of specific members of the community. The Public Library Services Branch of the BC Ministry of Education assists public libraries through grants, advice and information, training initiatives, interlibrary loan support and library-related publications (Government of British Columbia, 2007).

Funding for public libraries in BC is based on per capita operating grants. These grants must be used to purchase library materials or to pay general operating expenses. Under the Act, funding may be withheld or reduced if the amount allocated by the government exceeds local support, thus local communities and municipalities must also contribute to the funding of the public libraries. Per capita grants range from $\$ 2.00$ to $\$ 4.00$ (as of 2005), with smaller communities and regional libraries serving rural areas getting the higher rates. Per capita grants are calculated based on population estimates.

BC’s public library system, as of 2005, consists of 70 library boards and 235 service outlets, and employs over 2,023 full and part time staff including nearly 450 professional librarians.

\footnotetext{
Alberta

Public library entities in Alberta consist of municipal libraries, library systems, community libraries, and federations. Library boards established under the Alberta Public Libraries Act are in place for each type of body. Public library service is managed by the Libraries, Community and Voluntary Services Sector of Alberta Community Development. Under the Libraries Act, libraries may charge a fee for library cards, and the charging of an annual fee of up to \$20.00 in Alberta is nearly universal. One exception is the Banff Public Library (Madiros, 2001).
} 
Funding for public libraries in Alberta is regulated by the Community Development Grants Regulations. Library boards receive operating grants, and to be eligible for provincial funding, a municipal library board must get a minimum of $\$ 2.00$ per resident from the municipality. Municipal rates range from $\$ 2.00$ to $\$ 64.00$ per capita. The provincial per capita grant is a maximum of $\$ 4.29$ for each resident of the municipality. Library boards serving small communities receive a flat grant based on population. Provincial operating grants are also paid to each system board.

As of 2005, there were 228 municipal boards, 1 community library board, 7 library system boards, and 310 library sites.

\section{Saskatchewan}

Saskatchewan public library entities are classified as municipal or local libraries, regional library systems, and the Northern library system under the Public Libraries Act. The Provincial Library, under the Saskatchewan Department of Learning, coordinates the province-wide public library system. The Provincial Library also administers The Libraries Co-operation Act, which established the Multitype Library Board. The Board facilitates co-operation among all types of libraries in the province: public, academic, school and special libraries (Saskatchewan Provincial Library, 2007). The Provincial Library, run by the Provincial Librarian, has a cooperative relationship with the public library systems. Public libraries in the province are governed by library boards.

In addition to the municipal libraries for the cities of Saskatoon and Regina, Saskatchewan has seven regional library systems to serve the central and southern regions of the province. Northern Saskatchewan is sparsely populated and some areas are accessible only by air. The Northern Library System, called the Pahkisimon Nuye?ah Library System (PNLS), acts as the central library for that area, and is a coordinating agency for school, regional college, public, and special libraries. The PNLS cooperates with the Saskatchewan Provincial Library to maintain provincewide library services. 
Funding is provided locally by municipalities and provincially by government grants. There are three funding pools for regional libraries, municipal libraries, and the northern library system. The policy around funding is to support resource sharing. Local, operational services are supported locally.

\section{Manitoba}

Manitoba public libraries fall into the categories of municipal public libraries, regional libraries, and federations of regional and municipal public libraries under the Public Libraries Act. The Winnipeg Public Library, in the province's capital city of Winnipeg, also falls under the City of Winnipeg Act. Municipal corporations are responsible for determining the format of public library services in their communities. Each of the 54 rural library systems has a separate governing board. The Winnipeg Public Library, as it falls under the jurisdiction of the City, is limited to an advisory board. The Public Library Services Branch, in the Department of Culture, Heritage, and Tourism, ensures that all Manitobans have access to public library services by overseeing many of the traditional provincial library services roles, including interlibrary loan, block rotations, and the books-by-mail service. This Branch is overseen by a Director of Libraries.

Library funding consists of a matching provincial per capita grant of $\$ 8.50$ for rural and northern public libraries, while the City of Winnipeg gets funds equal to $11 \%$ of its operating budget. As of 2005, Manitoba had 55 library systems (or regions) with a total of 108 public libraries.

\section{Ontario}

As per the Ontario Public Libraries Act, this province consists of public libraries, union libraries, and county libraries. A municipality can provide library services by establishing a public library or by joining with one or more municipalities to form a union public library. A county library may be established when two-thirds of the municipalities in a county request it. Public libraries fall under the auspices of the Ministry of Culture. The Programs and Services Branch develops policies for the public library system. Ontario Library Service - North and the Southern Ontario Library Service deliver programs on behalf of the ministry. The Toronto Public Library is seen as a special entity that provides library resources and services to the Ontario library community. 
The provincial government provides annual grants for library purposes to libraries and to organizations that contract for library services. Grants also are provided by the municipalities themselves. Operating grant amounts are calculated based on \$4.08 per household for urban areas and $\$ 4.80$ per household for rural areas. First Nation library grants are calculated at $\$ 1.50$ per capita.

\section{Quebec}

Quebec is unique in that most of the public libraries there are municipally integrated, meaning they have no public library board of trustees. Public libraries are municipal services akin to garbage collection and street maintenance. The administration of the municipality governs the public library, is responsible for development of services, and ideally ensures adequate financial support. Quebec is also unique in that currently, the province does not have a Public Libraries Act. There was a law from 1950 to 1970 which enabled the creation of 73 new libraries in Quebec. A new law in the 1970s positioned public libraries under the Ministère des Affaires Culturelles. This law was repealed in 1992, with the appearance of a new law for the Ministère de la Culture. The new law apparently leaves much out: "This law no longer includes the principle of free access to public libraries, among other lacks” (O’Neill, 2007). Anecdotal evidence suggests that this issue is currently being revisited in Quebec (Kloda, 2007).

Research by Diane Mittermeyer attempts to discern if the development of Quebec public libraries compares to the growth of public libraries in other provinces. Mittermeyer's research, which used data from Statistics Canada, found that out of 86 library characteristics, only 14 were perceived as essential (Mittermeyer, 1990). And the perception of being an essential service is important when there is competition for funds among services which perhaps are perceived as more essential.

LibDex, the online library index, lists 91 public libraries situated in Quebec (Bisca, 2007). 


\section{New Brunswick}

New Brunswick public libraries are partnerships between the provincial government and participating municipalities. Public libraries are under the auspices of the Department of PostSecondary Education, Training, and Labour. The New Brunswick Public Library Services, led by a Provincial Librarian, is responsible for the management and development of library services, thus ensuring the intent of the Public Libraries Act. Governance falls under the New Brunswick Public Libraries Board and individual library boards for municipal and association libraries.

Funding in New Brunswick is weighted heavier from the provincial side, with the provincial government providing approximately $70 \%$ of the budget and $30 \%$ of the budget coming from participating municipalities.

\section{Prince Edward Island (PEI)}

Community and district libraries as outlined in the Public Libraries Act in PEI are the responsibility of the Ministry of Community and Cultural Affairs within the Division of Culture, Heritage, and Libraries. The Provincial Library Service, under a Provincial Librarian, enhances and supports public library services in terms of general management and operations, including policy, planning, staffing, collections, and technical services, and the funding of these services. The local community, where the library is physically located, is responsible for all financial aspects of the library facility. When an agreement between the provincial government and the municipality is entered into to provide local library services, a library board is appointed at the local level. There are 26 local libraries facilities in PEI.

\section{Nova Scotia}

Public library service is available to every municipality in Nova Scotia under the auspices of the Department of Education. There are municipal libraries and regional library systems. The Provincial Library, a Division of the Higher Education Branch of the Department, provides leadership and coordinates library services throughout the province. A Provincial Librarian is appointed. Regional library boards are in place to deal with issues at the local level. As do most other provinces, Nova Scotia follows the provincial Libraries Act. 
Funding is made available jointly through the province and the municipalities. The latter are required to raise a portion of their annual operating budgets and are responsible for the physical facility at their location.

\section{Newfoundland and Labrador}

Local libraries, regional libraries, and the St. John’s Public Library are all run by library boards in Newfoundland and Labrador. The Provincial Information and Library Resources Board operates all public libraries under the Public Libraries Act.

Funding primarily comes from the province. Monetary funds coming from elsewhere are extremely low. Despite this, municipalities often contribute in kind in the form of free rent, utilities, maintenance, etc. on local library facilities. Because of the small population, and thus the small tax base, of Newfoundland and Labrador, it has been surmised that if library services were transferred to the municipalities, many sites would close.

There are 96 public libraries in the province, 210 full and part time permanent staff, and a centralized technical services division. Other services provided at the provincial level include human resources, finances, and information technology services.

\section{Yukon}

The Public Libraries unit in the Yukon is a unit of the Community Development Branch of the Department of Community Services. The Public Libraries unit manages a network consisting of a central library and 14 community libraries. The central library houses all the resources and is administered by a Director of Libraries. The Whitehorse Public Library Board governs the Whitehorse Public Library in the capital city of the Yukon. Volunteer branch libraries can be established anywhere there is not a community library, under the Yukon Public Libraries Act.

Funding is transferred from the Public Libraries unit to the community library boards, which hire and pay staff to operate community libraries. Funding is calculated using a population-based formula to determine opening hours for the community libraries. The Public Libraries unit provides collections, supplies, furnishings, computers, and high speed Internet access to 
community libraries. There is centralized cataloguing, distribution, inter-library loan, reference service, programming, and promotion.

\section{Northwest Territories (NWT)}

The fifteen community libraries and several virtual libraries spread throughout the Northwest Territories are managed locally by municipal governments and overseen by the NWT Public Library Services (PLS), a unit of Education, Operations and Development within the Department of Education, Culture and Employment, and under the direction of the Territorial Librarian. The PLS provides collections and technical services for eight of the libraries (the Yellowknife Public Library in the capital city maintains its own) and maintains a rotating collection. There is also a free "borrower by mail" service to residents in communities without libraries. The public libraries are governed by the Northwest Territories Library Act.

Funding arrangements are specific to each community in NWT. Contribution agreements are in place for some of the communities, while one community receives no direct funding. Individual libraries use donations, grants, and municipal funding to augment collections.

\section{Nunavut}

Nunavut is the largest and newest of the Canadian Territories. It was separated from the Northwest Territories in 1999 along boundaries that were put in place in 1993. The name means "Our Land" in the Inuit language. The territory covers just over 1.9 million square kilometers of land and water, and is home to a population of just under 30,000 (Statistics Canada, 2006). The Nunavut Public Library Services (NPLS) operates as part of the Division of Culture and Heritage in the Nunavut Department of Culture, Language, Elders \& Youth (CLEY). Current to 2005, the Northwest Territories Library Act governs the Nunavut Public Library Services. There are 11 community libraries, including the Iqaluit Centennial Library located in Iqaluit, the capital city. Local libraries have library boards in place.

Funding is provided by the territorial government through a combination of government sponsored facilities and a system of community contribution agreements. The territorial government provides staff and materials funding to community libraries, and funding for the 
administrative headquarters in Baker Lake. For additional funding and resources, the public library system has formed partnerships with a wide array of private and public organizations including ABC CANADA Literacy Foundation and Starbucks Coffee Canada Gift of Words' ${ }^{\mathrm{TM}}$, Bill and Melinda Gates Foundation, Calm Air International, Community Access Program Industry Canada, the National Film Board of Canada (NFB), TD Summer Reading Club, and TechSoup (Nunavut Public Library Services, 2006).

\section{ISSUES SURROUNDING PUBLIC LIBRARIES IN CANADA}

While each province is responsible for providing publicly funded library services to its constituents, there are some common issues that cross provincial and territorial borders. The demographics of librarianship and succession planning are concerns across the country. As Wendy Newman reported in 2004, the population of librarians is maturing, and there could be a shortage of librarians in the next five to ten years. In addition to demographics, another issue is one of staff skills shortages. While public libraries are committed to responding to cultural diversity and technological change, skill levels can sometimes lag behind real time movement. Newman reports that "there is an urgent and growing need for specially trained library staff to strengthen service to Aboriginals, youth at risk, and multicultural groups” (2004). Additionally, marketing, communication, and advocacy skills are needed to present the story of Canada's libraries to the decision-makers and funding bodies.

Another issue that fits in with the idea of technological change is the need for widespread public internet access. In many communities, especially among people in lower economic brackets, the public library is the only place to access the internet. There are many communities across the country, particularly those in rural and remote areas, where internet access still is not available. Gaps in technology creating technological "haves" and "have nots" is an issue that continues to be addressed. The Community Access Program (CAP) is a federal initiative from Industry Canada put in place to ensure affordable public internet access to Canadians and provide them with the skills to use the technology. Libraries have been logical choices to house CAP computers. In the spring of 2004, CAP was reduced by 44\% (Newman 2004). And further cuts in 2006 mean that issue is not resolved. 
The Library Book Rate is a hot topic in Canada. The Library Book Rate originated in 1939 and was designed to level the playing field by giving all Canadians the opportunity to obtain reading and educational materials from libraries in Canada. The Book Rate is a concessionary postal rate designed to ensure access to library materials for people who might not otherwise have access to service. A press release from the Canadian Library Association explains the Book Rate this way: The Library Book Rate provides special postal rates for libraries to ship books to other libraries and to readers, allowing libraries to loan more books and encourage more reading. The Library Book Rate is especially important to Canada's rural and remote libraries by helping Canadians borrow books regardless of where they live. Special rates for shipping library books have been in place since 1939 but are subject to regular review. Without the special Library Book Rate, libraries would pay over $\$ 10$ for the same service they receive for $\$ 0.81$ today (Canadian Library Association, 2006).

93.78\% of public libraries use the Library Book Rate and 1,269 public library systems ship approximately 2,696,619 packages a year (Labuik, 2005). In 2005, Canada Post announced that it was going to discontinue the existing book rate, which led to lobbying activities from libraries and library associations across the country. The issue surrounding the Book Rate centres on where the funds will come from to support its continuation. Currently Canada Post (the national Canadian postal system) is funded for this program by an agreement with Canadian Heritage. The Library Book Rate has been extended by Canada Post through 2008.

Many issues of concern to public libraries in Canada center on funding. Dependence on local, provincial/territorial, and federal funding means that often the libraries are at the whim of those in power. Budgetary cuts are common across Canada, as governments at all levels look to save money and often deem libraries as "less essential.” The issue of Alberta public libraries charging a fee for library cards for residents apparently arose from funding cuts at the provincial level. A further concern to funding is the population drain in certain areas of the country. Rural areas are often hardest hit by declining populations. A lower population means a lower tax base, and when funding is often based on per capita calculations, the funding issues can be quite drastic.

Library service to Aboriginal people is also an issue that is being addressed at different levels across the country. "Administrative, cultural and social barriers” often stand in the way of both the providing of and the accessing of library services (Joseph and Lawson, 2003). Several of the Library Acts include encouraging partnerships with First Nations groups as part of the public 
library mandate. However, quite often, the direct mandate does not include the provision of public library services to First Nations. Many provinces are taking steps to rectify this situation. For example, in Saskatchewan a Minister's Advisory Committee on Library Services for Aboriginal People was formed in 2001 to examine issues surrounding access. Several initiatives are in place because of this committee's report.

\section{CONCLUSION}

There are many issues of concern to public libraries in Canada, and several different ways in which libraries are set up and managed. In an overview such as this, in-depth analyses of the subtleties of the legislation, the different types of libraries, and the issues public libraries face are not possible. Further research could be undertaken on any of these topics, with useful and interesting results. The goal of this work has been to bring together in one place a synopsis of the public library structure in Canada, and an introduction to some of the issues surrounding public libraries.

Public libraries are a life line in a country where vast land expanses can dwarf the population. Libraries are democratizing agents, making information available to everyone. Despite such barriers as remote populations, funding cuts, and fees for library cards, public library systems across the country find ways to work with what they have. Almost ten times more people visit public libraries in Canada every year than attend Canadian National Hockey League games in the three most recent years combined (OCLC, 2004). If they are more popular than hockey in Canada, public libraries must be doing something right!

\section{REFERENCES}

Bisca International Investments, Ltd. (2005) “Geographic: Countries: Canada: Quebec.” LibDex: The Library Index. 6 Feb. 2007. Available at: http://www.libdex.com/country/CanadaQuebec.html

Boadway, Robin. (2006) “Canada: Emerging Issues in a Decentralized Federation.” 26 Feb. 2008. Available at: http://www.mng.gov.pk/icfd/worldbank

Canadian Library Association. (2006) National library associations pleased with extension of Canada Post Library Book Rate. Media Release. 7 Feb. 2007. Available at: 


\section{http://www.cla.ca/issues/LBR_media_release060829.pdf}

Government of British Columbia. BC Public Library Services. (2007) Programs and Services for Libraries, 7 Feb. 2007. Available at: http://www.bced.gov.bc.ca/pls/services.htm

Joseph, G. and Lawson K. (2003) "First Nations and British Columbia Public Libraries.” Feliciter Vol.5, pp. 245-47

Kloda, L. (2007) “Quebec Public Libraries Question.” E-mail to author. 2 Feb. 2007

Labuik, K. and Pilikowski C., eds. (2005) “Advocacy @ your library.” Letter of the LAA. Issue 7. 7 Feb. 2007. Available at: http://laa.ab.ca/admin/uploads/2/2_62.pdf

Mapleleafweb. (2008) "Federalism in Canada: Basic Framework and Operation."

Mardiros, S. (2001) “Banff’s Very Public Library.” Alberta Views, 7 Feb. 2007. Available at: http://www.banfflibrary.ab.ca/news/abview.html

Mittermeyer, D. (1990) “Quebec Public Libraries and Their Municipal Environment.” Canadian Library Journal Vol 47 No 2, pp. 113-115

Newman, W. (2004) Public Libraries in the Priorities of Canada: Acting on the Assets and Opportunities. 7 Feb. 2007. Available at: http://www.collectionscanada.ca/obj/s7/f2/03 e.pdf

Nunavut Public Library Services. (2006) About Nunavut Public Libraries. 6 Feb. 2007. Available at: http://www.publiclibraries.nu.ca/about.html

OCLC Canada. (2004) Libraries: How They Stack Up, Canadian edition. OCLC Online Computer Library Center, Inc.8 Feb. 2007. Available at: http://www5.oclc.org/downloads/community/librariesstackupcanada_en.pdf

O’Neill, M. (2007) “Quebec Public Libraries Question.” E-mail to author. 8 Feb. 2007.

Saskatchewan Provincial Library. Saskatchewan Libraries. (2007) Multitype Library Board. 6 Feb. 2007. Available at: http://www.lib.sk.ca/staff/multitype/

Statistics Canada. (2006) “Nunavut.” 19 Nov2007. Available at:

http://www12.statcan.ca/english/census06/data/profiles/community/Details/Page.cfm?Ln g=E\&Geo1=PR\&Code1=62\&Geo2=PR\&Code2=01\&Data=Count\&SearchText=Nunaut\&Searc hType $=$ Begins $\&$ SearchPR $=01 \& B 1=$ All \&Custom $=$

\section{WORKS CONSULTED}

Canadian Library Association. (2008) Letter to the Canadian Community Newspaper Association. 
3 Mar. 2008. Available at:

http://www.cla.ca/AM/Template.cfm?Section=Library_Book_Shipping_Tool_Outil_d_expan deacute_dition_de_livres_de_bibliothandegrave_que

Government of Alberta. Municipal Affairs and Housing. (2006) Building Strong Communities. 7

Feb. 2007. Available at:

http://www.cd.gov.ab.ca/building_communities/public_library/index.asp

Government of Manitoba. Manitoba Culture, Heritage, and Tourism. (2007) Public Library

Services. 7 Feb. 2007. Available at: http://www.gov.mb.ca/chc/maplin/index.html

Government of New Brunswick. Department of Post-Secondary Education, Training and Labour. (2007) New Brunswick Public Library Services. 7 Feb. 2007. Available at: http://www.gnb.ca/0003/index-e.asp

Government of Nova Scotia. Department of Education. (2007) Nova Scotia Provincial Library. 7

Feb. 2007. Available at: http://www.library.ns.ca/

Government of Ontario. Ministry of Culture. (2007) Libraries. 7 Feb. 2007.

http://www.culture.gov.on.ca/english/culdiv/library/index.html

Government of Prince Edward Island. Community and Cultural Affairs. Public Libraries. 7 Feb.

2007. http://www.gov.pe.ca/cca/index.php3?number=1004338\&lang=E

Government of Saskatchewan. Saskatchewan Learning. (2007) Province-Wide Public Library

System. 6 Feb. 2007. Available at:

http://www.sasked.gov.sk.ca/branches/prov_library/pubsystem.shtml

Government of the Northwest Territories. (2003) NWT Public Library Services. 2 Mar. 2008.

Available at:

http://www.ece.gov.nt.ca/Public_Library_Services/About_NWT_PublicLibraryServices. $\underline{\mathrm{html}}$

Government of Nunavut. Department of Culture, Language, Elders, and Youth. (2007) Nunavut Public Library Systems. 7 Feb. 2007. Available at: http://www.gov.nu.ca/cley/home/english/libraries.html>.

Libraries Act Chapter 254 of the Revised Statutes. Office of the Legislative Counsel, Nova Scotia House of Assembly: 1989. 6 Feb. 2007. Available at: http://www.gov.ns.ca/legislature/legc/statutes/librarie.htm

Libraries Act [RSA 2000] Chapter L-11. Queen’s Printer: Edmonton, Alberta. 6 Feb. 
2007. Available at: http://www.qp.gov.ab.ca/Documents/acts/L11.CFM

Library Act [RSBC 1996] CHAPTER 264. Queen’s Printer: Victoria, British Columbia. 6

Feb. 2007. Available at: http://www.qp.gov.bc.ca/statreg/stat/L/96264_01.htm

LIBRARY ACT, R.S.N.W.T. 1988, c. L-7. Territorial Printer, Northwest Territories:

Yellowknife, N.W.T. 1997. CanLII. 6 Feb. 2007. Available at:

http://www.canlii.org/nt/laws/sta/l 7/20061114/whole.html

McNally, P. (2002) “Libraries in Canada: A Précis,” Feliciter, 2 pp. 75-7

New Brunswick Public Libraries Act Chapter N-7.01. Government of New Brunswick. 6 Feb.

2007. Available at: http://www.gnb.ca/acts/acts/n-07-01.htm

Newfoundland and Labrador Public Libraries. (2005) Newfoundland and Labrador Public

Libraries. 7 Feb. 2007. Available at: http://www.nlpubliclibraries.ca/

Nova Scotia Department of Education. (2008) About Public Libraries. 3 Mar. 2008.

Available at: http://www.library.ns.ca/regionals/aboutrls.htm

Provincial and Territorial Library Directors Council (PTLDC) Annual Reports. (2004 and 2005)

7 Feb. 2007. Available at: http://www.collectionscanada.ca/6/7/s7-502-e.html

Public Libraries Act Chapter B-3. Quebec. Available at:

http://www2.publicationsduquebec.gouv.qc.ca/dynamicSearch/telecharge.php?type=2\&f le=\%2F\%2FB_3\%2FB3_A.htm

Public Libraries Act Chapter P-31.1. Legislative Council Office, Prince Edward Island: 2003.

6 Feb. 2007. Available at: http://www.gov.pe.ca/law/statutes/pdf/p-31_1.pdf

Public Libraries Act [RSNL 1990] CHAPTER P-40. Queen’s Printer: St. John's, Newfoundland and Labrador. 2006. 6 Feb. 2007. Available at: http://www.hoa.gov.nl.ca/hoa/statutes/p40.htm

Public Libraries Act [R.S.O. 1990] CHAPTER P.44. Government of Ontario. 6 Feb. 2007. Available at: http://www.e-laws.gov.on.ca/DBLaws/Statutes/English/90p44_e.htm

Public Libraries Act, R.S.Y. 2002, c. 178. Queen’s Printer for the Yukon. CanLII . 6 Feb. 2007. Available at: http://www.canlii.org/yk/laws/sta/178/20060728/whole.html

Public Libraries Act [1996] Chapter P-39.2 of the Statutes of Saskatchewan. Queen's Printer: Regina, Saskatchewan. 2006. 6 Feb. 2007. Available at: http://www.qp.gov.sk.ca/documents/English/Statutes/Statutes/P39-2.pdf 
Saskatchewan Provincial Library. Saskatchewan Libraries. (2007) Minister's Advisory Committee on Library Services for Aboriginal People. 8 Feb. 2007. Available at: http://www.lib.sk.ca/staff/minaboriginal/structure.html

The Libraries Co-operation Act [1996] Chapter L-14.01 of the Statutes of Saskatchewan. Queen’s Printer: Regina, Saskatchewan. 1997. 6 Feb. 2007. Available at: http://www.qp.gov.sk.ca/documents/English/Statutes/Statutes/L14-01.pdf

The Public Libraries Act C.C.S.M. c. P220. Government of Manitoba. 6 Feb. 2007 Available at: http://web2.gov.mb.ca/laws/statutes/ccsm/p220e.php

\section{ADDITIONAL READING}

Canadian Heritage. Publications Assistance Program. (2003) Historical and Public Policy Overview. Available at: http://canadianheritage.gc.ca/progs/ac-ca/progs/pap/pubs/tlb-lbr/03_e.cfm

Fitch, L. and Warner J. (1998) "Dividends: the value of public libraries in Canada," The Bottom Line: Managing Library Finances Vol 11 No 4, pp. 158-79

Mardiros, S. (2001) “Librarians' Views on Membership Fees in Alberta: Survey Results,” Feliciter Vol 47 No 6, pp. 284-5.

Royal Commission on National Development in the Arts, Letters and Sciences, 1949-1951 [also know as Massey Commission]. (1951) Report. Ottawa: Edmond Cloutier, Printer to the King's Most Excellent Majesty. 7 Feb. 2007. Available at: http://www.collectionscanada.ca/2/5/h5400-e.html 